\title{
ZASIEDZENIE FIZYCZNEJ CZĘŚCI NIERUCHOMOŚCI ODDANEJ W UŻYTKOWANIE WIECZYSTE
}

\section{WSTĘP}

Użytkowanie wieczyste, pomimo swojej dość długiej obecności w polskim systemie prawnym, nie przestaje budzić kontrowersji, tym samym stanowi bardzo interesujący obszar badawczy polskiej cywilistyki. Instytucja ta miała zastapić własność czasową jako formę korzystania z nieruchomości państwowych, ta ostatnia bowiem nie odpowiadała ówcześnie funkcjonującej zasadzie jednolitego funduszu własności państwowej. Ustawodawca nie zdecydował się na ulokowanie użytkowania wieczystego w katalogu ograniczonych praw rzeczowych, dość niefortunnie umiejscawiając je pomiędzy nimi a najpełniejszym z praw rzeczowych - własnościa. Od tamtej pory konstrukcja ta budzi liczne kontrowersje. Dyskusyjny jest już jej charakter prawny ${ }^{1}$. Przekłada się to na szczegółowe problemy odnoszące się do sytuacji prawnej osób uwikłanych w relacje dotyczące nieruchomości oddawanych w użytkowanie wieczyste. Sytuacja ta, z powodu konieczności odpowiedniego stosowania niekiedy przepisów o własności, a niekiedy o ograniczonych prawach rzeczowych, jest częstokroć dość niejasna. Przedmiotem niniejszego artykułu uczyniono problematykę zasiedzenia fizycznych części nieruchomości oddanych w użytkowanie wieczyste. Zagadnienie to niezwykle istotne z praktycznego punktu widzenia wymaga szerszej analizy teoretycznej, a to z uwagi na trudności wynikające zarówno z charakteru użytkowania wieczystego, jak i samej przedmiotowej zdolności do zasiedzenia części fizycznej nieruchomości. Celem artykułu jest wskazanie na możliwość zasiedzenia części takiej nieruchomości, co w praktyce stanowi bardzo częste zjawisko, oraz, co istotne, ustalenie konsekwencji takiego zasiedzenia. Przedmiotem użytkowania wieczystego może być jedynie grunt, a zatem dalsze rozważania dotyczyć będą nieruchomości gruntowych.

1 Szczegółowego przeglądu poglądów na charakter prawny omawianej instytucji dokonał Z. Truszkiewicz, Użytkowanie wieczyste. Zagadnienia konstrukcyjne, Kraków 2006, s. 154 i n. 


\section{CZĘŚĆ NIERUCHOMOŚCI JAKO PRZEDMIOT ZASIEDZENIA}

Punkt wyjścia dalszych rozważań stanowi ustalenie przedmiotowej zdolności do zasiedzenia fizycznej części nieruchomości. Zasiedzeniu podlegaja rzeczy, a dokładniej określone prawo do rzeczy, sformułowanie „zasiedzenie rzeczy" jest bowiem w istocie skrótem myślowym². Prawo do rzeczy zazwyczaj wiąże się z przyznaniem danemu podmiotowi prawa cywilnego pewnego władztwa nad rzecza, co może wytworzyć mylne przekonanie, że w istocie to rzecz, sama w sobie, stanowi przedmiot zasiedzenia. Lege non distinguente, przedmiotem prawa podlegającego zasiedzeniu może być jakakolwiek rzecz niewyłączona z obrotu ${ }^{3}$, ergo zarówno rzecz ruchoma, jak i nieruchomość a zatem grunty, budynki i lokale, które na mocy szczególnego przepisu stanowia przedmiot odrębnej własności ${ }^{4}$. Natomiast jeszcze przed wejściem w życie obowiązującego Kodeksu cywilnego ${ }^{5}$ w doktrynie sformułowane zostały podstawowe cechy prawa, które może być przedmiotem zasiedzenia. Pierwszą wymaganą cechą jest majattkowy charakter takiego prawa, należącego do kategorii praw prywatnych, druga - przynależność tego prawa do kategorii praw rzeczowych, trzecią - możność posiadania w zakresie takiego prawa, natomiast ostatnia cechą jest, co do zasady, zbywalność tego prawa ${ }^{6}$. W analizowanym przypadku zasiadywanym prawem miałaby być własność. Oczywiste jest, że prawo własności podlega zasiedzeniu, ponad wszelką wątpliwość bowiem ma charakter majątkowy, jest zbywalne, a także możliwe jest posiadanie $\mathrm{w}$ zakresie odpowiadającym temu prawu. Problem stanowi jednak status fizycznej części nieruchomości, należy pamiętać, iż de lege lata własność odnosi się jedynie do rzeczy?

Nieruchomością gruntową stosownie do art. 46 k.c. jest część powierzchni ziemskiej, która stanowi odrębny przedmiot własności, tworząc materialna i gospodarczą całość. Istotne jest tu kryterium wyodrębnienia - w znaczeniu fizykalnym - pozwalające na stanowienie przez ową część powierzchni ziemskiej przedmiotu własności. Wyodrębnienie to ma charakter konwencjonalny ${ }^{8}$, trudno bowiem w odniesieniu do gruntów uzyskać wyodrębnienie z przyrody właściwe rzeczom ruchomym. Oceny wyodrębnienia dokonuje się zatem zgodnie z kryterium własności ${ }^{9}$ oraz uprzedniego geodezyjnego wydzielenia danego

2 S. Rudnicki, Nabycie przez zasiedzenie, Warszawa 2010, s. 23; W. Hans, J. Ignatowicz, Dwugłos w sprawie zasiedzenia udziału we współwłasności, „Nowe Prawo” 1956, nr 9, s. 107.

${ }^{3}$ A. Kunicki, Zasiedzenie w prawie polskim, Warszawa 1964, s. 84; S. Rudnicki, op. cit., s. 23; postanowienie SN z 6 kwietnia 2016 r., IV CSK 414/15, Lex nr 2053643.

${ }^{4}$ Z. Radwański, A. Olejniczak, Prawo cywilne - część ogólna, Warszawa 2015, s. 114-115.

5 Ustawa z 23 kwietnia 1964 r. - Kodeks cywilny (t.jedn.: Dz. U. 2017, poz. 459); dalej jako: k.c.

${ }^{6}$ W. Hans, J. Ignatowicz, op. cit., s. 104.

7 Zob. J. Ignatowicz, K. Stefaniuk, Prawo rzeczowe, Warszawa 2012, s. 18; Z. Żabiński, Wptyw pojęcia rzeczy na kształtowanie się systemu prawa cywilnego, „Zeszyty Naukowe Uniwersytetu Jagiellońskiego. Prace z wynalazczości i ochrony własności intelektualnej” 1974, z. 1, s. 254.

${ }^{8}$ Por. B. Swaczyna, Prawne wyodrębnienie gruntu na powierzchni ziemskiej, „Rejent” 2002, nr 9, s. 96.

9 Zob. ibidem, s. 91. 
fragmentu powierzchni ziemskiej ${ }^{10}$. Niebagatelne znaczenie mają tutaj regulacje dotyczące ustroju ksiag wieczystych. Nie ulega wątpliwości, że status odrębnej nieruchomości ma geodezyjnie wydzielony fragment powierzchni ziemskiej, dla którego urządzona jest księga wieczysta. Podobnie jedną odrębną nieruchomość stanowić będzie kilka geodezyjnie wydzielonych działek, dla których prowadzona jest jedna księga wieczysta ${ }^{11}$. Jednakże w braku księgi wieczystej własność może być wykazywana za pomocą innych dowodów ${ }^{12}$. Założenie i prowadzenie księgi wieczystej nie stanowi warunku istnienia nieruchomości gruntowej ${ }^{13}$. Pamiętać jednak należy, że dla powstania użytkowania wieczystego niezbędny jest wpis tego prawa do księgi wieczystej nieruchomości obciążonej, co niejako implikuje urządzenie księgi wieczystej dla takich nieruchomości.

Cała nieruchomość gruntowa w obrębie wydzielonej działki (bądź działek), dla której prowadzona jest jedna księga wieczysta, stanowi rzecz w rozumieniu prawa cywilnego. Taka fizyczna część gruntu może prima facie nasuwać skojarzenia z instytucją części składowych, odnoszącej się wszak zarówno do nieruchomości, jak i rzeczy ruchomych ${ }^{14}$. Konsekwencją uznania danego przedmiotu za część składową rzeczy jest pozbawienie go statusu samoistnego przedmiotu jakichkolwiek praw rzeczowych, na co wprost wskazuje art. $47 \S 1$ k.c. Przedmiotem tych praw może być jedynie rzecz ${ }^{15}$. Część składowa ponadto nie może stanowić przedmiotu posiadania samoistnego ${ }^{16}$ ani nie podlega zasiedzeniu $^{17}$. Konstrukcję posiadania samoistnego części składowych uznaje się za nieprawidłową ${ }^{18}$. Nie ma przeszkód, by części składowe były przedmiotem posiadania zależnego ${ }^{19}$.

10 E. Gniewek, Prawo rzeczowe, Warszawa 2014, s. 28; S. Rudnicki, Własność nieruchomości, Warszawa 2012, s. 72.

11 Wyrok SN z 26 lutego 2003 r., II CKN 1306/00, Lex nr 83961; postanowienie SN z 30 października 2003 r., IV CK 114/02, Lex nr 131941.

12 S. Rudnicki, Wtasność..., s. 74.

${ }_{13}$ B. Swaczyna, op. cit., s. 92. Należy jednak zauważyć, że niekiedy wpis do księgi wieczystej będzie miał charakter konstytutywny dla powstania określonej nieruchomości gruntowej (tak: ibidem, s. 97-105).

${ }_{14}$ M. Bednarek, Mienie. Komentarz do art. 44-55 Kodeksu cywilnego, Kraków 1997, s. 142; Z. Radwański, A. Olejniczak, op. cit., s. 118.

15 T. Dybowski, Części sktadowe rzeczy, „Nowe Prawo” 1969, nr 1, s. 80; M. Bednarek, op. cit., s. 147; E. Gniewek, Komentarz do art. $47 \mathrm{KC}$, w: idem, P. Machnikowski (red.), Kodeks cywilny. Komentarz, Warszawa 2013, s. 120; idem, Prawo..., s. 31; E. Niezbecka, Komentarz do art. 47 KC, w: A. Kidyba (red.), Kodeks cywilny, t. 1: Część ogólna, Warszawa 2012, s. 275-276; J. Ignatowicz, K. Stefaniuk, op. cit., s. 25.

${ }_{16}$ M. Bednarek, op. cit., s. 149; E. Gniewek, Komentarz do art. 47 KC..., s. 120; E. Skowrońska-Bocian, Komentarz do art. 47 KC, w: K. Pietrzykowski (red.), Kodeks cywilny, t. 1: Komentarz. Art. 1-44911, Warszawa 2015, s. 148.

17 Postanowienie SN z 19 stycznia 1988 r., III CRN 459/87, Lex nr 8858; E. Gniewek, Komentarz do art. 47 KC..., s. 120; E. Niezbecka, op. cit., s. 275.

18 Zob. postanowienie SN z 19 stycznia 1988 r., III CRN 459/87, Lex nr 8858; J. Gołaczyński, Posiadanie, w: E. Gniewek (red.), System prawa prywatnego, t. 3, Warszawa 2013, s. 100.

19 Z. Radwański, A. Olejniczak, op. cit., s. 119; J. Ignatowicz, Ochrona posiadania, Warszawa 1963, s. 59-60. 
Rozpatrywanie przypadku fizycznie wydzielonej części gruntu kontekście przepisów o częściach składowych byłoby jednak błędne. Zagadnienie części składowych dotyczy wyłącznie rzeczy złożonych, czyli takich, w których daja się wyróżnić elementy mające samodzielne znaczenie ${ }^{20}$. Natomiast grunt rozumiany jako wydzielony fragment powierzchni ziemskiej należy zakwalifikować jako rzecz prosta, stanowi bowiem jednorodna, jednolitą całość ${ }^{21}$. Odłączenie fizycznej części gruntu nie spowoduje zmiany gospodarczego charakteru ani przeznaczenia zarówno części odłączanej, jak i pozostałej22. Przesądza to o braku podstaw do kwalifikowania takiej fizycznej części gruntu jako części składowej nieruchomości.

Nie rozwiąuje to jednak problemu braku samoistności jako przedmiot obrotu takiej części nieruchomości, która co prawda nie jest częścią składowa nieruchomości, to jednak nadal nie stanowi odrębnej rzeczy w rozumieniu prawa cywilnego. Niemniej zarówno w orzecznictwie, jak i w doktrynie dopuszcza się możliwość nabycia wskutek zasiedzenia fizycznej części nieruchomości gruntowej $^{23}$. Dopuszczenie takiej możliwości jest o tyle interesujące, że samoistne posiadanie to faktyczne władanie rzeczą jak właściciel, ergo władztwo dotyczyć ma rzeczy, a więc nie jej częśsici ${ }^{24}$.

Pomimo pewnych wątpliwości, wynikających z jurydycznej konstrukcji posiadania samoistnego, należy przyłączyć się do stanowiska aprobującego możliwość nabycia własności fizycznie wydzielonej części nieruchomości gruntowej przez zasiedzenie, a zatem dopuszczenia posiadania samoistnego części rzeczy. Nie przekonuje jednak uzasadnienie takiego odstępstwa jedynie nawiązaniem do tradycji rzymskich czy wypowiedziami judykatury międzywojennej ${ }^{25}$. Dopuszczalności takiego rozwiązania należy dopatrywać się raczej w konwencjonalnym charakterze wyodrębnienia nieruchomości gruntowych oraz ich podzielności w powiązaniu z funkcjami zasiedzenia. Należy bowiem pamiętać, że prawne wyodrębnienie ma tu charakter myślowy, ponieważ nie

${ }^{20}$ M. Bednarek, op. cit., s. 57; A. Brzozowski, W.J. Kocot, E. Skowrońska-Bocian, Prawo cywilne. Część ogólna, Warszawa 2015, s. 163; W.J. Katner, Rzeczy proste i rzeczy złożone. Części sktadowe rzeczy, w: M. Safjan (red.), System prawa prywatnego, t. 1: Prawo cywilne - część ogólna, Warszawa 2012, s. 1311-1312.

${ }^{21}$ Oczywiście grunt wraz z połączonymi z nim budynkami, urządzeniami czy roślinami stanowić będzie rzecz złożona, jednakże w rozpatrywanym przykładzie chodzi o grunt w znaczeniu wyodrębnionej części powierzchni ziemskiej.

${ }^{22}$ Zob. S. Grzybowski, Przedmioty stosunków cywilnoprawnych, w: idem (red.), System prawa cywilnego, t. 1, Wrocław 1985, s. 417.

${ }_{23}$ J. Piątowski, Zasiedzenie, w: J. Ignatowicz (red.), System prawa cywilnego, t. 2, Wrocław 1977, s. 317-318; E. Janeczko, Zasiedzenie, Warszawa-Zielona Góra 2000, s. 124-125; J. Wszołek, Nabycie udziału we wspótwłasności nieruchomości w drodze zasiedzenia, „Transformacje Prawa Prywatnego" 2011, nr 2, s. 54; uchwała SN z 19 grudnia 1968 r., III CZP 106/68, Lex nr 850; postanowienie SN z 5 stycznia 1972 r., II CR 534/71, Lex nr 7047; uchwała SN z 26 stycznia 1978 r., III CZP 96/77, Lex nr 2246; postanowienie SN z 30 sierpnia 2006 r., II CSK 53/06, Lex nr 201183; postanowienie SN z 21 stycznia 2009 r., III CSK 229/08, Lex nr 503222; postanowienie SN z 4 marca 2011 r., I CSK 352/10, Lex nr 848114; postanowienie SN z 1 kwietnia 2011 r., III CSK 184/10, Lex nr 863394.

${ }^{24}$ Zob. J. Gołaczyński, op. cit., s. 100.

${ }^{25}$ Taką argumentację przedstawia E. Janeczko, op. cit., s. 124-125. 
jest możliwe uzyskanie, właściwego rzeczom ruchomym, wyraźnego wyodrębnienia z przyrody. Dopuszczalne jest - w granicach zakreślonych ustawą $^{26}$ - modyfikowanie kształtu takich nieruchomości. Nieruchomości gruntowe podlegaja bowiem zarówno podziałowi geodezyjnemu, polegającemu na wydzieleniu z istniejącej działki ewidencyjnej dwóch lub więcej działek, jak i podziałowi prawnemu, polegającemu na przeniesieniu w drodze czynności prawnej własności części nieruchomości ${ }^{27}$. Zasiedzenie ma natomiast na celu wyeliminowanie długotrwałej rozbieżności między stanem prawnym nieruchomości a rzeczywistym wykonywaniem wobec niej uprawnień właścicielskich ${ }^{28}$. Jak słusznie zauważa Edward Janeczko, zasiedzenie stanowi również swoistego rodzaju sankcję dla właścicieli, którzy zaniedbują nieruchomości stanowiące ich własność, co ma skłaniać ich do starannego działania w odniesieniu do należących do nich rzeczy ${ }^{29}$.

Należy pamiętać, że ratio legis tej jakże daleko ingerującej w prawo własności instytucji ${ }^{30}$ stanowi ochrona pewności obrotu prawnego. Niemniej ochrona prawa własności wymaga, aby możliwość nabycia własności nieruchomości w drodze zasiedzenia była w odpowiedni sposób ograniczona. Dlatego też ustawodawca uzależnia nabycie własności tą drogą od spełnienia wymagających przesłanek, zawartych w art. $172 \S 1$ k.c. Konieczne jest, po pierwsze, samoistne posiadanie rzeczy oraz po drugie, upływ oznaczonego w ustawie czasu, który w zależności od tego, czy podmiot wszedł w posiadanie rzeczy w dobrej albo złej wierze, wynosi odpowiednio dwadzieścia albo trzydzieści lat. Wskutek zrealizowania koniecznych przesłanek zasiedzenia własność nieruchomości przechodzi na nieuprawnionego posiadacza, natomiast dotychczasowy właściciel prawo to traci ${ }^{31}$. Skoro zatem dany podmiot zachowuje się wobec wyodrębnionej, fizycznej części nieruchomości tak, jakby była ona przedmiotem jego odrębnej własności, to należałoby dopuścić zakwalifikowanie tego posiadania jako samoistnego ${ }^{32}$ ad usucapionem, fragment objęty władztwem będzie bowiem mógł stanowić odrębny przedmiot własności, bez konieczności spełnienia dodatkowych warunków ${ }^{33}$. Konstrukcję taką zdaje się aprobować sam ustawodawca, przewiduje bowiem w art. 95 pkt 3 u.g.n., że podział nieruchomości może nastapić wbrew ustaleniom miejscowego planu zagospodarowania przestrzennego, jeśli jej część została nabyta z mocy prawa - a zatem także w wyniku zasiedzenia. Niekorzystne z punktu widzenia obrotu prawnego by-

26 Szczególne znaczenie będą tu miały przepisy ustawy z 21 sierpnia 1997 r. o gospodarce nieruchomościami (t.jedn.: Dz. U. 2016, poz. 2147); dalej jako: u.g.n.

27 G. Bieniek, Podziat nieruchomości, w: G. Bieniek, S. Rudnicki, Nieruchomości. Problematyka prawna, Warszawa 2013, s. 521.

28 E. Gniewek, Nabycie i utrata własności, w: idem (red.), System prawa prywatnego, t. 3, Warszawa 2013, s. 633; E. Janeczko, op. cit., s. 26 i n.; J. Nadler, Komentarz do art. 172 KC, w: idem, P. Machnikowski (red.), Kodeks cywilny. Komentarz, Warszawa 2013, s. 328.

29 E. Janeczko, op. cit., s. 28.

30 Wyrok TK z 28 października 2003 r., P 3/03, OTK-A 2003, nr 8, poz. 82.

31 J. Ignatowicz, K. Stefaniuk, op. cit., s. 105 i n.; J. Nadler, op. cit., s. 331; E. Janeczko, op. cit., s. 11; S Rudnicki, Nabycie..., s. 141.

32 J. Ignatowicz, op. cit., s. 60; E. Gniewek, Nabycie..., s. 636.

33 E. Gniewek, Nabycie..., s. 636. 
łoby utrzymywanie sytuacji, w której podmiot niebędący właścicielem zachowuje się wobec fragmentu gruntu jak jego właściciel, wykonuje swe władztwo przez okres co najmniej dwudziestu lat, mimo że własność przypada innemu podmiotowi, niezainteresowanemu losem rzeczy.

Konkludując, należy uznać, że pomimo pewnych zastrzeżeń, z uwagi na podzielność nieruchomości gruntowych oraz funkcje instytucji zasiedzenia, należy dopuścić możliwość nabycia własności fizycznej części nieruchomości gruntowej w drodze zasiedzenia. W konsekwencji dojdzie do powstania nowej nieruchomości ${ }^{34}$, niezależnie od tego, czy zasiadującym był właściciel sąsiadującego gruntu czy też zupełnie inna osoba. Gdy zasiadującym jest właściciel nieruchomości sąsiadującej, będzie on mógł połączyć zasiedzianą nową nieruchomość ze swoją dotychczasowa ${ }^{35}$. Konieczność taka wynika z odrębności prawnej dotychczasowej nieruchomości, w szczególności gdy urządzona jest dla niej osobna księga wieczysta. Dopuszczalne będzie nabycie w drodze zasiedzenia fizycznej części zabudowanej nieruchomości, o ile tylko nie dojdzie do pionowego podziału budynku, w wyniku którego powstaną niesamodzielne części takiego budynku ${ }^{36}$.

Niezwłocznie należy zauważyć, że w sytuacji, w której niemożliwe będzie zasiedzenie wyodrębnionej części fizycznej nieruchomości albo części składowej, która po spełnieniu pewnych, stawianych przez prawo, wymogów będzie mogła stać się odrębna rzecza, może dojść do zasiedzenia udziału we współwłasności takiej nieruchomości ${ }^{37}$.

\section{DOPUSZCZALNOŚĆ ZASIEDZENIA NIERUCHOMOŚCI ODDANEJ W UŻYTKOWANIE WIECZYSTE}

Zasiedzenie nieruchomości państwowych w czasie obowiązywania art. 177 k.c. było wyłączone ${ }^{38}$, co $\mathrm{w}$ konsekwencji przesądzało o niedopuszczalności zasiadywania nieruchomości oddawanych w użytkowanie wieczyste. Jednakże z chwilą uchylenia wspomnianego przepisu wyraźne podstawy normatywne wykluczające taką możliwość przestały istniećs ${ }^{39}$, co zaktualizowało problem nabywania takich nieruchomości wskutek zasiedzenia. Pomimo uchylenia art. 177 k.c. i zaakceptowania możliwości zasiedzenia nieruchomości oddanej w użytkowanie wieczyste ${ }^{40}$, pojawiają się również głosy

34 Ibidem.

${ }^{35}$ Dotyczy to także nieruchomości, która wraz z nabytym fragmentem stanowić będzie gospodarczą całość.

36 E. Janeczko, op. cit., s. 125-127.

${ }^{37}$ Postanowienie SN z 6 czerwca 1973 r., I CR 413/73, Lex nr 7265.

38 Zakaz taki częściowo funkcjonował od 21 lipca 1961 r. na podstawie ustawy z 14 lipca 1961 r. o gospodarce terenami w miastach i osiedlach, natomiast w całości od 1 stycznia 1965 r. już na podstawie art. 177 k.c.

39 Zob. S. Rudnicki, Nowe problemy zasiedzenia, „Monitor Prawniczy” 1996, nr 7, s. 231.

${ }^{40}$ Zob. E. Janeczko, op. cit., s. 55; M. Warciński, Zasiedzenie gruntu oddanego w użytkowanie wieczyste (na tle orzecznictwa Sadu Najwyższego), „Monitor Prawniczy” 2014, nr 19, s. 1035-1037; 
temu przeciwne ${ }^{41}$. Uzasadnienie stanowiska sprzeciwiającego się zasiedzeniu opiera się w zasadzie na charakterze użytkowania wieczystego i wynikajacych z niego relacji zachodzących pomiędzy właścicielem, użytkownikiem wieczystym i osobami trzecimi ${ }^{42}$. Najsilniej pogląd ten reprezentuje Zygmunt Truszkiewicz ${ }^{43}$, który wskazuje, że skoro użytkowanie wieczyste polega na scedowaniu przez właściciela na użytkownika wieczystego uprawnień właścicielskich - przy zachowaniu tego prawa dla siebie - to użytkownik wieczysty i tylko on wchodzi w ogół relacji prawnorzeczowych z innymi podmiotami ${ }^{44}$. Zdaniem tego autora właścicielowi nie przyznano prawnych instrumentów pozwalających mu przeciwstawić się władaniu nieruchomością oddana w użytkowanie wieczyste przez osobę trzecią. Za odrzuceniem rozważanej tu dopuszczalności zasiedzenia przemawiać ma jeszcze okoliczność, że wiązałoby to się z koniecznością monitorowania przez właściciela losów owej nieruchomości. W związku z tym nawet posiadaczowi samoistnemu proponuje się jedynie możliwość zasiedzenia prawa użytkowania wieczystego.

Należy przychylić się, mimo wskazanych argumentów, do stanowiska przeciwnego, aprobujacego dopuszczalność zasiedzenia własności nieruchomości oddanej w użytkowanie wieczyste. Podejmując to zagadnienie, Sąd Najwyższy w uchwale składu 7 sędziów z 9 grudnia 2016 r. ${ }^{45}$ potwierdził możliwość nabycia własności nieruchomości oddanej w użytkowanie wieczyste w drodze zasiedzenia.

Ustosunkowując się do twierdzeń przeciwników takiego poglądu, należy w pierwszej kolejności sprzeciwić się traktowaniu ustanowienia użytkowania wieczystego jako scedowania na użytkownika wieczystego uprawnień właścicielskich ${ }^{46}$. Prowadziłoby to $\mathrm{w}$ istocie do uznania, że ustanowienie prawa na rzeczy cudzej powoduje przejście na uprawnionego wycinka prawa własności. Taki pogląd jest z kolei nie do zaakceptowania z uwagi na implikowanie niedopuszczalności ustanowienia kilku praw rzeczowych na rzeczy cudzej o tożsamej treści, co stoi w sprzeczności z konstrukcją ius in re aliena $\mathrm{w}$ prawie polskim ${ }^{47}$. Przyjęcie takiego stanowiska naruszałoby zasadę numerus clausus praw rzeczowych, właściciel bowiem, przelewając część przysługujących mu

\footnotetext{
A. Suchoń, Komentarz do art. 240 KC, w: M. Gutowski (red.), Kodeks cywilny, t. 1: Komentarz do art. 1-44911, Warszawa 2016, s. 1021, jednakże autorka, w innym miejscu (eadem, Komentarz do art. $237 \mathrm{KC}$, w: M. Gutowski (red.), op. cit., s. 1005) zdaje się prezentować pogląd o niedopuszczalności zasiedzenia własności nieruchomości oddanej w użytkowanie wieczyste; postanowienie SN z 18 stycznia 2008 r., V CSK 383/07, Lex nr 394753; postanowienie SN z 6 kwietnia 2016 r., IV CSK 414/15, Lex nr 2053643; uchwała SN [7] z 9 grudnia 2016 r., III CZP 57/16, Lex nr 2162855; postanowienie SN z 25 stycznia 2017 r., IV CSK 799/15, Lex nr 2242292.

41 Zob. Z. Truszkiewicz, Użytkowanie..., s. 510-511; postanowienie SN z 14 marca 2012 r., II CSK 127/11, Lex nr 1170220; postanowienie SN z 16 października 2014 r., III CSK 299/13, Lex nr 1554585 .

42 Ibidem.

43 Z. Truszkiewicz, Użytkowanie..., s. 510-511.

${ }_{44}$ Pogląd o wyłączeniu uprawnień właściciela podziela również E. Gniewek, Glosa do uchwaty SN z 7.4.2006 r., III CZP 24/06, „Orzecznictwo Sądów Polskich” 2007, z. 10, s. 752.

45 Uchwała SN [7] z 9 grudnia 2016 r., III CZP 57/16, Lex nr 2162855.

46 Tak: M. Warciński, op. cit., s. 1035-1037.

${ }^{47}$ M. Warciński, op. cit., s. 1035-1036.
} 
uprawnień, tworzyłby nowe prawo własności o treści ograniczonej o scedowane uprawnienia ${ }^{48}$.

Warte odnotowania jest to, że wyżej przytoczony argument ma de facto charakter pomocniczy, gdyż stanowi uzasadnienie tezy o pozbawieniu właściciela instrumentów prawnej reakcji na nieuprawnione władanie nieruchomością przez osobę trzecia. Wyłączenie możliwości zasiedzenia własności nieruchomości oddanej w użytkowanie wieczyste ma stanowić swoistego rodzaju ochronę właściciela przed negatywnymi konsekwencjami takiego ograniczenia jego uprawnień właścicielskich. Twierdzenie to należy uznać za chybione. Otóż ustanowienie użytkowania wieczystego nie powoduje wygaśnięcia - wynikających z prawa własności - roszczeń petytoryjnych i posesoryjnych ${ }^{49}$. Uprawnienia te są immanentnie związane z prawem własności ${ }^{50}$. Właściciel może - stosownie do art. $222 \S 1$ k.c. - żądać od osoby władającej jego rzecza, aby została mu ona wydana. Roszczenie to może zostać skierowane przeciwko każdemu, kto rzeczą włada, a zatem zarówno wobec posiadacza samoistnego, zależnego, a nawet dzierżyciela. Jedynym ograniczeniem tego żądania jest przysługiwanie podmiotowi sprawującemu władztwo skutecznego przeciwko właścicielowi uprawnienia do władania rzecza, przy czym uprawnienie takie może mieć charakter rzeczowy albo obligacyjny ${ }^{51}$. W konsekwencji właściciel nie będzie mógł skutecznie dochodzić zwrotu rzeczy od uprawnionego użytkownika wieczystego, z uwagi na przysługujące mu prawo użytkowania wieczystego. Roszczenie windykacyjne właściciela będzie tu ograniczone, jednakże nie wygaśnie ${ }^{52}$. Będzie ono jednak w pełni skuteczne przeciwko każdemu, kto włada rzecza bez tytułu prawnego, nawet w sytuacji oddania gruntu w użytkowanie wieczyste $^{53}$. Ustanowienie takiego - nawet bardzo zbliżonego do własności - prawa rzeczowego nie powoduje scedowania uprawnień właścicielskich na uprawnionego. Nie jest wyłączone zatem dochodzenie przez właściciela roszczenia windykacyjnego przeciwko każdemu, kto nie będzie w stanie skutecznie przeciwstawić się takiemu żądaniu, wykazując stosowne uprawnienie. Pomijając nawet nietrafność tezy o wyłączeniu uprawnień właściciela, podkreślić należy, że zakładając wyłączenie uprawnień właściciela, należałoby uznać zasiedzenie takiej nieruchomości za dopuszczalne ${ }^{54}$. Wynika to z samej istoty i funkcji

${ }^{48}$ M. Warciński, op. cit., s. 1035-1036; E. Drozd, Numerus clausus praw rzeczowych, w: S. Sołtysiński (red.), Problemy kodyfikacji prawa cywilnego. Studia i rozprawy. Ksiega pamiatkowa ku czci Prof. Z. Radwańskiego, Poznań 1990, s. 266.

${ }^{49}$ Zob. T. Smyczyński, Ochrona prawa wieczystego użytkowania, „Palestra” 1971, nr 3, s. 2224; M. Warciński, op. cit., s. 1036.

50 T. Dybowski, Ochrona własności w polskim prawie cywilnym (rei vindicatio - actio negatoria), Warszawa 1969, s. 115.

51 Ibidem, s. 286.

52 Ibidem.

53 Zob. T. Smyczyński, Ochrona..., s. 217 i n.; M. Warciński, op. cit., s. 1036; P. Bender, Zasiedzenie prawa własności nieruchomości oddanej w użytkowanie wieczyste, „Rejent” 2014, nr 7, s. 37-38; M. Krajewski, Zasiedzenie w stosunkach zwiazanych z użytkowaniem wieczystym, w: M. Nazar (red.), Prawo cywilne - stanowienie, wyktadnia i stosowanie. Ksiega pamiatkowa dla uczczenia setnej rocznicy urodzin Profesora Jerzego Ignatowicza, Lublin 2015, s. 210.

${ }_{54}$ Tak trafnie: M. Krajewski, op. cit., s. 210-211. 
zasiedzenia jako instytucji porządkującej stan prawny rzeczy, który w sposób długotrwały pozostaje w opozycji do stanu faktycznego, zwiększając tym samym pewność obrotu.

Nie sposób się również zgodzić z twierdzeniem, że na właścicielu nieruchomości nie spoczywa obowiązek, czy wręcz pozbawiony jest on realnej możliwości, monitorowania losu swojej nieruchomości oddanej w użytkowanie wieczyste. Należy pamiętać, że zasiedzenie może nastapić dopiero po upływie określonego ustawą czasu: dwudziestu lat w przypadku posiadacza w dobrej wierze albo trzydziestu lat $\mathrm{w}$ przypadku wystapienia złej wiary. Właściciel musiałby zatem nie wykazywać zainteresowania nieruchomościa przez kilkadziesiąt lat, co zasługuje na dezaprobatę. W szczególności że najczęściej objęcie takiej nieruchomości w posiadanie samoistne wiązać się będzie z zaprzestaniem uiszczania opłaty rocznej5 ${ }^{55}$, co jednak najczęściej nie będzie miało miejsca w przypadku posiadania ad usucapionem jedynie fizycznej części gruntu. Zważywszy jednak, że mamy do czynienia z posiadaniem samoistnym, to jego wykonywanie musi być w dostateczny - widoczny dla innych - sposób zamanifestowane ${ }^{56}$, co powinno zwrócić uwagę właściciela rzeczy. Nie można tracić z pola widzenia, że właścicielem w omawianym przypadku jest podmiot publiczny, wobec którego można stawiać wyższe wymagania i który dysponuje większą liczbą środków ułatwiających monitorowanie własnego mienia, niż podmiot prywatny ${ }^{57}$.

Nie kontestując w tym miejscu możliwości nabycia w drodze zasiedzenia istniejącego już prawa użytkowania wieczystego ${ }^{58}$, sprzeciwić się trzeba poglądowi uznającemu, że uzukapient posiadajacy samoistnie nieruchomość oddaną w użytkowanie wieczyste może nabyć jedynie prawo użytkowania wieczystego. Instytucja zasiedzenia dotyczy wprost prawa własności (oraz na mocy art. 292 k.c. służebności gruntowych), natomiast w odniesieniu do użytkowania wieczystego stosowana jest jedynie per analogiam. Rudymentarna przesłanką zasiedzenia jest posiadanie samoistne, na które składają się dwa elementy: fizyczny (corpus possessionis), czyli faktyczne władztwo nad rzecza, oraz psychiczny (animus rem sibi habendi), a zatem władanie rzecza jak jej właściciel, niezależnie od rzeczywistego stanu prawnego ${ }^{59}$. Odróżnić trzeba właścicielskie posiadanie samoistne od posiadania w zakresie użytkowania

55 Por. ibidem, s. 210.

56 Zob. szerzej nt. manifestacji objęcia w posiadanie samoistne: K.P. Sokołowski, Manifestacja animi rem sibi habendi, „Przegląd Sądowy” 2014, nr 10, s. 94 i n.

${ }^{57}$ M. Warciński, op. cit., s. 1036; P. Bender, op. cit., s. 43-44; M. Krajewski, op. cit., s. 210.

58 Zob. J. Winiarz, Użytkowanie wieczyste, Warszawa 1967, s. 227-233; G. Bieniek, Z. Mamraj, Użytkowanie wieczyste w praktyce. Problematyka prawna, Warszawa-Zielona Góra 1999, s. 99-100; Z. Truszkiewicz, Użytkowanie..., s. 508; C. Woźniak, Użytkowanie wieczyste, Warszawa 2006, s. 141-144; S. Rudnicki, Nabycie..., s. 50-52; uchwała SN [7] z 11 grudnia 1975 r., III CZP 63/75, Lex nr 2001; uchwała SN z 23 lipca 2008 r., III CZP 68/08, Lex nr 408410; uchwała SN z 28 marca 2014 r., III CZP 8/14, Lex nr 1444966; postanowienie SN z 14 kwietnia 2011 r., IV CSK 446/10, Lex nr 1124113.

59 J. Ignatowicz, K. Stefaniuk, op. cit., s. 326 i n. wraz z przywoływaną tam literaturą i orzecznictwem; E. Skowrońska-Bocian, Komentarz do art. $336 \mathrm{KC}$, w: K. Pietrzykowski (red.), Kodeks cywilny. Komentarz, t. 1, Warszawa 1999, s. 681. 
wieczystego, które nie są tożsame ${ }^{60}$. Posiadanie w zakresie użytkowania wieczystego jest $\mathrm{w}$ istocie szczególnego rodzaju odmianą posiadania zależnego ${ }^{61}$, które to ma polegać na władaniu rzeczą jak podmiot mający określone prawo do rzeczy. Ustawodawca nie ograniczył posiadania zależnego wyłącznie do władztwa w zakresie ograniczonych praw rzeczowych. Jak wynika wprost z art. 336 k.c., dotyczy ono każdego władztwa cudzą rzeczą w swoim imieniu. Skoro zatem użytkowanie wieczyste należy do kategorii iura in re aliena, to posiadanie rzeczy w zakresie tego prawa należy zakwalifikować jako posiadanie zależne. Nie stanowi natomiast przekonującego argumentu wskazanie na odmienność charakteru użytkowania wieczystego od przykładowo wskazanych praw do rzeczy wymienionych wprost $\mathrm{w}$ art. 336 k.c. ${ }^{2} \mathrm{~W}$ konsekwencji odnotować trzeba, że posiadanie samoistne nieruchomości oddanej w użytkowanie wieczyste nie będzie prowadziło do nabycia w drodze zasiedzenia tego prawa na rzeczy cudzej, lecz prawa własności ${ }^{63}$.

Rekapitulując, należy zaaprobować dopuszczalność nabycia w drodze zasiedzenia własności nieruchomości oddanej w użytkowanie wieczyste. Odnosząc powyższe uwagi do analizowanego w niniejszym artykule zagadnienia, należy w drodze rozumowania a maiori ad minus zaakceptować możliwość zasiedzenia własności fizycznej części nieruchomości oddanej w użytkowanie wieczyste. Skoro bowiem dopuszczalne jest zasiedzenie całej takiej nieruchomości, to tym bardziej dozwolone będzie zasiedzenie fragmentu takiej nieruchomości - oczywiście mając na uwadze wyżej poczynione zastrzeżenia.

\section{SKUTKI ZASIEDZENIA}

Podstawowym skutkiem zasiedzenia jest nabycie własności rzeczy posiadanej samoistnie przez wymagany prawem $\operatorname{czas}^{64}$. Aczkolwiek w przypadku posiadania ad usucapionem fizycznie wydzielonej części gruntu nie dojdzie do nabycia własności istniejacej uprzednio rzeczy, lecz dojdzie do podziału rzeczy i powstania w ten sposób nowej rzeczy - w zakresie objętym posiadaniem samoistnym - której własność przypadnie uzukapientowi. Dotychczasowemu właścicielowi przysługiwać będzie własność gruntu zubożonego o zasiedziany jego fragment, który zostaje prawnie oderwany od nieruchomości macierzystej.

Pojawia się jednak pytanie o los użytkowania wieczystego ustanowionego na nieruchomości, której fizycznie wydzielona część zostanie nabyta wskutek

${ }^{60}$ Por. uchwała SN z 23 lipca 2008 r., III CZP 68/08, Lex nr 408410; uchwała SN z 28 marca 2014 r., III CZP 8/14, Lex nr 1444966.

${ }^{61}$ Zob. J. Winiarz, Komentarz do art. 233 KC, w: idem (red.), Kodeks cywilny z komentarzem, Warszawa 1980, s. 193; Z. Truszkiewicz, Użytkowanie..., s. 304-316; idem, Posiadanie w zakresie użytkowania wieczystego, „Studia Iuridica Agraria” 5, 2005, s. 229.

62 Jak się zdaje, taki argument prezentuje J. Gołaczyński w: idem, op. cit., s. 78.

63 Zob. M. Warciński, op. cit., s. 1037; M. Krajewski, op. cit., s. 211.

64 Zob. A. Kunicki, op. cit., s. 13; S. Rudnicki, Nabycie..., s. 141. 
zasiedzenia. Użytkowanie wieczyste niewątpliwie wygaśnie na tej części gruntu, która stanowiła przedmiot zasiedzenia i której własność została nabyta jako nowej nieruchomości. Najczęściej nabywca takiej nieruchomości będzie tzw. podmiot prywatny, niebędący Skarbem Państwa lub jednostką samorządu terytorialnego. Należy przypomnieć, że użytkowanie wieczyste nie może zostać ustanowione na gruncie nienależącym do Skarbu Państwa lub jednostki samorządu terytorialnego, nawet gdyby podmiot taki był współwłaścicielem gruntu $^{65}$. Co więcej, nie jest to możliwe również, gdy nabywca działa w dobrej wierze i w zaufaniu do księgi wieczystej6 ${ }^{66}$. Los użytkowania wieczystego na tak zasiedzianym gruncie jest przesądzony ze względu na konstrukcję tego prawa, która nie znosi w przedstawionym zakresie wyjątków, a zatem prawo to wygaśnie.

Nie jest jednak przyczyną wygaśnięcia użytkowania wieczystego pozbawienie użytkownika wieczystego władztwa nad gruntem, a tym samym długotrwałe niewykonywanie przez niego przysługującego mu prawa. W przeciwieństwie do niektórych ograniczonych praw rzeczowych użytkowanie wieczyste nie wygasa wskutek jego długotrwałego niewykonywania ${ }^{67}$, natomiast zasiedzenie jest skierowane przeciwko właścicielowi nieruchomości, a nie przeciwko podmiotom, których prawa obciążają rzecz ${ }^{68}$. Z tych samych względów nie wygasna - zarówno na nieruchomości macierzystej, jak i powstałej wskutek zasiedzenia - ustanowione przed wystapieniem skutku zasiedzenia ograniczone prawa rzeczowe. W odniesieniu do hipoteki ustawodawca przewidział natomiast wprost $\mathrm{w}$ art. 76 ustawy o księgach wieczystych i hipotece ${ }^{69}$, że obciąża ona wszystkie powstałe w wyniku podziału nieruchomości, tworząc tym samym hipotekę łączną. Odmiennie przedstawia się jednak los prawa rzeczowych obciążających użytkowanie wieczyste, stosownie bowiem do art. 241 k.c. wygasną one $\mathrm{e}^{70}$. Lege non distinguente nastapi to w każdym przypadku wygaśnięcia użytkowania wieczystego, a zatem również w przypadku zasiedzenia nieruchomości obciążonej tym prawem bądź jej części.

W przypadku zasiedzenia zabudowanej części nieruchomości budynki stanowiące uprzednio odrębną własność użytkownika wieczystego na powrót staną się częścią składową gruntu w myśl zasady superficies solo cedit (art. 48 k.c. i art. 191 k.c.). Warte podkreślenia jest, że użytkownikowi wieczystemu nie będa przysługiwały względem uzukapienta roszczenia o wynagrodzenie za

${ }^{65}$ Zob. uchwała SN [7] z 23 września 1993 r., III CZP 81/93, Lex nr 3959; wyrok NSA z 28 września 2000 r., I SA 1398/99, Lex nr 57194.

${ }^{66}$ Por. wyrok SN z 21 czerwca 1968 r., III CRN 139/68, Lex nr 839; wyrok SN z 14 maja 1986 r., II CR 28/86, Lex nr 3273.

${ }^{67}$ J. Winiarz, Użytkowanie..., s. 320; T. Smyczyński, Wygaśnięcie użytkowania wieczystego, „Palestra” 1971, nr 7-8, s. 16.

${ }^{68}$ Zob. J. Piątowski, op. cit., s. 340; J. Nadler, op. cit., s. 331; E. Gniewek, Prawo..., s. 122; J. Ignatowicz, K. Stefaniuk, op. cit., s. 111; wyrok SN z 29 grudnia 1967 r., III CR 59/67, Lex nr 696; uchwała SN z 8 czerwca 1977 r., III CZP 41/77, Lex nr 2135.

${ }^{69}$ Ustawa z 6 lipca 1982 r. o księgach wieczystych i hipotece (t.jedn.: Dz. U. 2017, poz. 1007); dalej jako: u.k.w.h.

${ }^{70}$ Przeciwnie: B. Pawlak, Nabycie przez zasiedzenie własności oddanej w użytkowanie wieczyste, „Przegląd Sądowy” 2013, nr 9, s. 41. 
utracone budynki lub ich części, brak bowiem stosownej podstawy normatywnej do takich rozliczeń. Nadto warto odnotować, że skoro na objętym w posiadanie samoistne fragmencie gruntu znajdowały się budynki (lub ich części), których własność przypadała użytkownikowi wieczystemu (art. 235 § 1 k.c.), to również i one objęte byłyby samoistnym posiadaniem uzukapienta. Prowadziłoby to do nabycia ich w drodze zasiedzenia przez posiadacza, które to jednak nie może nastapić, $\mathrm{z}$ uwagi na wygaśnięcie użytkowania wieczystego.

Los użytkowania wieczystego na pozostałym właścicielowi nieruchomości oddanej w użytkowanie wieczyste gruncie nie jest tak oczywisty. Możliwe sa dwa rozwiązania: pierwsze, w którym użytkowanie wieczyste wygaśnie całkowicie, oraz drugie - utrzymujace to prawo. Za zbyt kategoryczne należałoby jednak uznać przyjęcie, że użytkowanie wieczyste wygasa całkowicie. Nie zachodzi tu zmiana kategorii podmiotu będącego właścicielem, co w konsekwencji pozwala na dalsze trwanie użytkowania prawa na tym - publicznym - gruncie. Ustawodawca nie przewidział wyraźnie, aby zasiedzenie fizycznej części nieruchomości oddanej w użytkowanie wieczyste powodowało całkowite wygaśnięcie tego prawa. Rozwiązanie takie prowadziłoby do daleko idących komplikacji - chociażby w relacji pomiędzy właścicielem rzeczy a użytkownikiem wieczystym - przy czym brak przekonujących argumentów przemawiajacych za uznaniem, przy braku wyraźniej podstawy normatywnej, że prawo to wygasa.

Niezwłocznie należy zauważyć, że konsekwencją zasiedzenia fragmentu nieruchomości oddanej w użytkowanie wieczyste będzie co do zasady aktualizacja uprawnienia właściciela do żądania rozwiązania umowy o ustanowienie użytkowania wieczystego. Stosownie do art. 240 k.c. oraz art. 33 ust. 3 u.g.n., jeżeli użytkownik wieczysty korzysta z nieruchomości w sposób oczywiście sprzeczny z jej przeznaczeniem określonym w umowie lub korzysta z niej w sposób sprzeczny z określonym w umowie, właściciel może żądać rozwiązania umowy ${ }^{71}$. Kluczowe znaczenie dla wspomnianego uprawnienia ma oznaczenie w umowie sposobu korzystania z gruntu, w braku bowiem takiego postanowienia umowa co prawda nie jest nieważna ${ }^{72}$, ale przyjmuje się, że niemożliwe będzie żądanie rozwiązania umowy z powołaniem na art. 240 k.c. lub art. 33 ust. 3 u.g.n. ${ }^{73}$ Bardziej jednak przekonuje pogląd o możliwości określenia takiego przeznaczenia nieruchomości (sposobu korzystania z niej) zgodnie ze społeczno-gospodarczym przeznaczeniem prawa ${ }^{74}$, co pozwoli właścicielowi skorzystać z uprawnienia żądania rozwiązania umowy. Doprowadzenie do definitywnej utraty fizycznej części nieruchomości oddanej w użytkowanie wieczyste wskutek zasiedzenia, zawsze będzie oczywiście sprzeczne z przeznaczeniem nieruchomości wynikającym z umowy o ustanowienie użytkowania wieczystego. Prowadzi to bowiem do skutku w postaci utraty

${ }^{71}$ Zob. A. Pyrzyńska, Rozwiazanie umowy użytkowania wieczystego, „Rejent” 1998, nr 10, s. 67.

72 Z. Truszkiewicz, Użytkowanie..., s. 193.

${ }^{73}$ Wyrok SN z 8 grudnia 2010 r., V CSK 168/10, Lex nr 794580.

${ }^{74}$ Wyrok SN z 19 listopada 2002 r., IV CKN 1476/00, Lex nr 533121; wyrok SN z 7 kwietnia 2016 r., III CSK 249/15, Lex nr 2022544. 
rzeczy bądź jej części, co nie może mieścić się w przysługującym użytkownikowi wieczystemu - nawet najszerzej zakreślonym - uprawnieniu do korzystania z gruntu. Uzasadnia to wystapienie przed sacdem powszechnym o rozwiązanie wiążącej strony umowy i doprowadzenie do wygaśnięcia użytkowania wieczystego w całości.

Wygaśnięcie użytkowania wieczystego powoduje po stronie dotychczasowego użytkownika wieczystego powstanie obowiązu zwrotu gruntu właścicielowi. W analizowanej sytuacji dochodzi jednak do utraty części nieruchomości, która została zubożona o zasiedziany fragment, co niewątpliwie prowadzi do uszczerbku w majątku właściciela, a zatem do powstania szkody. Użytkownik wieczysty ponosi na podstawie art. 471 k.c. odpowiedzialność za szkody wyrządzone przez nienależyte wykonanie zobowiązania ${ }^{75}$, które tutaj przybierze postać niewłaściwego korzystania z gruntu ${ }^{76}$. Odpowiedzialność ta obejmie również szkodę wyrządzoną przez korzystanie z nieruchomości, w sposób prowadzący do zasiedzenia jej fizycznej części. Niewątpliwie użytkownik wieczysty jako podmiot, który może korzystać z rzeczy z wyłączeniem innych osób, powinien dbać o stan powierzonej mu nieruchomości z dochowaniem należytej staranności. Powinien zatem dbać o to, by rzecz znajdująca się pod jego władztwem nie została utracona, choćby w części. Roszczenie to przedawni się z upływem trzech lat od zwrotu nieruchomości. Jednakże roszczenia związane z użytkowaniem wieczystym stają się wymagalne już z chwilą wygaśnięcia użytkowania wieczystego ${ }^{77}$, przy czym należy przyjąć, że chodzi tu o wygaśnięcie użytkowania wieczystego na nieruchomości pozostałej właścicielowi, a nie na zasiedzianym jej fragmencie.

\section{PODSUMOWANIE}

Przedmiotem posiadania samoistnego - będącego rudymentarną przesłanką zasiedzenia - mogą być co do zasady jedynie rzeczy. W konsekwencji zatem za nieprawidłową należałoby uznać konstrukcję posiadania ad usucapionem części rzeczy, które przeto nie stanowią przedmiotu odrębnej własności. Niemniej należy dopuścić objęcie w posiadanie prowadzące do zasiedzenia części fizycznych nieruchomości gruntowych. Podyktowane jest to potrzebami obrotu. Nadto nieruchomości gruntowe - z uwagi na ich konwencjonalne wyodrębnienie - nadają się do podziału, w wyniku którego powstać moga nowe nieruchomości stanowiące przedmiot odrębnej własności. Nie ma również przeszkód, by przedmiotem zasiedzenia był fragment nieruchomości oddanej w użytkowanie wieczyste. Ustalono, że po uchyleniu art. 177 k.c. ustały wszelkie normatywne przeszkody do nabywania nieruchomości oddanych w użytkowanie wieczyste. Brak również przekonujących argumentów przemawiających za wyłączeniem

75 Wyrok SN z 10 września 2015 r., II CSK 587/14, Lex nr 1844078

76 Zob. E. Drozd, Z. Truszkiewicz, Gospodarka gruntami i wywłaszczenie nieruchomości. Komentarz, Kraków 1995, s. 151; Z. Truszkiewicz, Użytkowanie..., s. 629.

77 A. Suchoń, Komentarz do art. 243 KC, w: M. Gutowski (red.), op. cit., s. 1026. 
takiej możliwości. W szczególności należy zaakceptować dopuszczalność zasiadywania nieruchomości oddanych w użytkowanie wieczyste, mając na uwadze funkcję i cel zasiedzenia jako instytucji eliminującej trwałą niezgodność stanu prawnego rzeczy ze stanem faktycznym. Rozumujac a maiori ad minus, możliwe będzie zasiedzenie własności fizycznej części nieruchomości oddanej w użytkowanie wieczyste. Skutkiem takiego zasiedzenia fragmentu nieruchomości będzie wygaśnięcie na nim użytkowania wieczystego, aczkolwiek użytkowanie wieczyste nadal będzie trwało na pozostałej właścicielowi nieruchomości. Możliwe będzie jednak żądanie rozwiązania przez właściciela umowy o oddanie w użytkowanie wieczyste gruntu, z uwagi na oczywiście sprzeczne z przeznaczeniem nieruchomości korzystanie z niej przez uprawnionego. Co istotne, użytkownik wieczysty będzie odpowiadał kontraktowo za szkodę w postaci utraty części nieruchomości.

mgr Adrian Malicki

Uniwersytet im. Adama Mickiewicza w Poznaniu

adrian.malicki@amu.edu.pl

\section{PRESCRIPTION BY OCCUPATION OF A PART OF REAL ESTATE IN PERPETUAL USUFRUCT}

\section{Sum mary}

Perpetual usufruct is an ius in re aliena of a complex legal nature. Its subject may only be a property owned by the State Treasury or a local government unit. Under Article 177 of the Polish Civil Code, prescription by occupation of property classified as public was excluded. When this Article was repealed, the normative barriers to acquisitive prescription of the ownership of real estate given in perpetual usufruct disappeared. This paper is a discussion concerning the possibility of acquiring ownership of a part of such property. First, the capability of a given part of real estate for prescription by occupation is established and next differing opinions and arguments against the possibility of acquiring ownership, or prescription by occupation of certain parts of real estate are presented. The arguments raised by the opponents of prescription by occupation have been critically assessed. Further, the consequences of such acquisitive prescription have been identified. The consequences of perpetual usufruct on the property in question have been examined and the fate of the part of the property acquired by the owner as well as that of the remaining part, analysed and compared. The civil liability of the perpetual usufruct holder has also been addressed. 